\title{
PUBLIC OPINIONS OF STAKEHOLDERS OF BENIDORM (SPAIN)
}

\author{
Tomás Mazón, Elena Delgado and José Antonio Hurtado \\ Cátedra de Estudios Turísticos "Pedro Zaragoza Orts" \\ University of Alicante (Spain)
}

\begin{abstract}
Benidorm is identified as one of the main tourist destinations in Spain, proved by its number of hotels, close to 150 with 60.000 beds. In addition, this city provides $\mathbf{3 5 0 . 0 0 0}$ apartments for tourists, considered their second residence. Benidorm is geographically located in the southeast cost of the Iberian Peninsula, surrounded by the Mediterranean Sea and well known as Costa Blanca.

The early development of Benidorm as a tourist destination started in the 50's and through the years, Benidorm has been forced to adapt its self to new requirements of its main visitors. Therefore, due the number of years that Benidorm is known as a holiday destination and adding the current economic crisis, this city has to face important changes in order to continue being considered a successful and updated tourist destination in Spain.

This article focuses its main objective to understand the problems and aspects to be improved. To do so, the authors have done close to 30 interviews to stakeholders directly involved within the tourism industry. From the responses obtained, the authors have done a depth analysis concluding that Benidorm needs to act in different but significant aspects. For example, the image should be improved, needing important investments. It is important to emphasize the riskiness described by the interviewees with reference to the dependence of Benidorm to two types of tourists, English visitors and the senior tourists. Additionally, the number of hotels in Benidorm is considered a privilege but the quality of the service provided is far from exceeding the expectations. And last but not least, in relation to those human resources working for the tourism industry, the responses were unanimous, failing in terms of qualification and salaries.
\end{abstract}

Index Terms-Benidorm, hotels, human recourses, stakeholders, tourist, and urban ambience.

\section{INTRODUCTON}

The main purpose of this article is to clarify the reality that Benidorm, as a tourist destination has to deal with. The information has been obtained from the public opinions of those who are directly implicated in the Tourism Industry. It is going to be questioned important fields. Firstly, the article is going to study how the respondents perceive the image and ambience of Benidorm. Coming up next, this paper is going to discuss how are the perceptions of stakeholders regarding the type of tourists arriving to this destination, then the opinions about the number of hotels and the quality that characterizes them. Finally, the study is going to analyze how the human resources are managed. To conclude, it is going to be reflected the assessment and future perspectives made from the social partners.

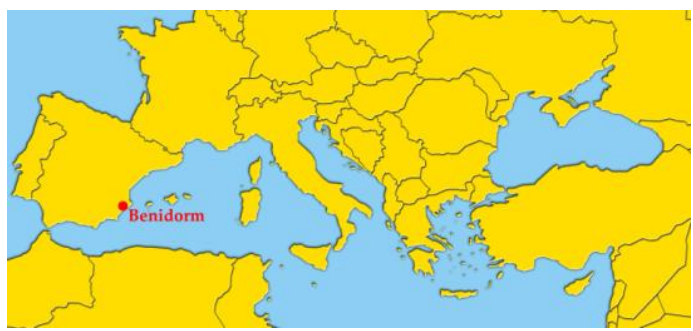

Location of Benidorm in the Mediterranean Sea.

The methodology followed throughout this paper is based in an empirical study, done from 30 in depth interviews along the months of February to May, 2011. From the answers obtained and the observation of the interviewers, the paper seeks to determine the real situation that Benidorm faces in terms of tourism, nowadays. Interviewees were selected carefully according to their professional profiles, knowledge about Benidorm [1], and with high level of influence and active participation in social and tourist live and local politcy [2] - hotel's associations, hotel managers, politics, bank managers, civil servants, merchant associations, restaurants owners, researchers and tourism students, journalists, trades union and employees of the industry - . The interviews were made with open and flexible questions.

\section{LANDSCAPE AND URBAN AMBIENCE}

The landscape and environment are considered crucial when the decision making process is taking place among all possible aspects that could give personality, character or identity to any tourist destination. It is not easy to dispose of these two elements considered raw material of tourist activities [3] and that represent the core assets for the attractiveness of a place. According to Antón [4] the image of a tourist destination has a great influence when tourists are evaluation the possible destinations, because it is what makes a place exceptional and different from the rest. Therefore, the 
perception of tourists about the chosen place and the image associated with it are considered key aspects to assess any holiday destination. Forecasting analysis

It is necessary large amount of resources, such as streets alive, daily and night activities, attractive shops, cafeterias, bars, restaurants, pubs, and so on to make a destination as tempting as possible for tourists. Another factor that should add value in tourism destinations is the city role. In other terms, the city itself is a product to sell, and a tourist should be able to visit and do many different things. A successful destination must combine avenues, streets, gardens, parks and buildings making the city as pleasant, attractive and charming as possible. To get a city with these characteristics involves an ambitious policy geared to constant improvements of the space and urban scene. This shall include a successful and adequate planning, from the beginning of its development ahead. Effective actions form the administration through economic aids, to improve, renew and increase infrastructures, are also needed to create a positive image. For instance, street lighting, well-paved sidewalks, urban facilities, roads, cleaning, garbage collection, accessibility, security and a long etcetera.

Besides, local businesses must improve consistently their companies to attract new tourist generations. In other words, an actualized agenda with appropriate refurbishment and renovation policies of hotels, restaurants, trades and any kind of tourism businesses to become the first destination for future tourists.

The consistency Benidorm' image is undeniable and the interviewers' opinions are conclusive. They praise Benidorm' urbanism and its ambience. Moreover, they consider the image as one of the elements that distinguish, characterize and give personality to the city, representing its main attraction. They are convinced that its ambience is superb all over the year. Likewise, the skyline focused on skyscrapers, mixing hotels with apartments, allows the concentration of large amount of people and all kind of services:

"...the skyline of Benidorm is known by everyone, do you know which skyline has Torremolinos or Valencia? The icon of Benidorm is its skyline and it is unique. (Hotel Staff)."

The urban ambience of Benidorm propitiates to visitors to walk around the sociable streets, full of people all over the year. This is one of the major differences of Benidorm in relation to other cities in which their development has been focused on what it is known as a residential tourism, where behind the high season, they are empty:

"...Benidorm has one thing that it's wonderful. Listen, when I was working in other coastal cities, at 9 p.m. I finished work and there was no one in the streets. I was scared, you could not find anyone around and in Benidorm it's totally the opposite, I have never seen before anywhere what happens in this city (Bank Manager)."

Despite these favorably estimations about Benidorm, the respondents perceive an unclear future. They believe Benidorm $t$ must face challenges to improve its urban space. However they also show skepticism claiming that due to the economic crisis and the vast lack of economic resources in Benidorm, - according to the newspaper "Diario Información" 04/05/2011 is 130 milion euros- it is very difficult to undertake all those priority actions to improve its image. Although Benidorm is considered an idyllic destination, the critics concerning its landscape are very severe. They perceive that in the last years, the town is in decline with an evident damage, mistreatment and degradation of its urban scene. They state that there is a lack on investment and that it is necessary to renew Benidorm because "it's a new city that is getting old and it has to be recycle permanently". (City Councilor of Partido Popular (PP)). In this sense, we collect two opinions:

“...It's essential to invest in the image of Benidorm, to renovate the street lighting. It is not possible to have 50 years old lampposts in one of the main avenues and to find asphalt above the pavement. This is not possible, because we live from the image of Benidorm (Politic PP)".

"...We have to change the image and give brightness to Benidorm. There are not parkings. In Poniente Beach there is an spectacular promenade, but there are not enough space to park more than two cars. They can only park in a patch, under a tree, like many years ago, how do they set up an impressive walk along the beach but they do not think about parking? In many places in Benidorm happens the same, there are not parking places (Trade representative)."

\section{TOURITS}

If we have been qualifying the landscape and urban ambience of a tourist destination as the row material, the tourist is its main character. Without tourists, there is no possibility of tourism. But all tourists are not equal. One classification of tourists may be according to their expenditure power. This social segmentation takes a leading role when tourists are deciding which destination to choose. Those with a healthy economy will opt for destinations 
matching their level of income, rejecting at the same time those territories characterized by mass tourism.

All tourist areas should aim to be within top, however they have to adapt to their reality.

Some destinations are specialized in what is well known as Sun and Sea. Since the beginning of the modern tourism, its clientele is being recruited by tour operators through tourist packages. These companies capture potential tourists with the price as a key element to decide where to spend their holidays, hence the existence of many destinations with high number of tourist arrivals. But the revenue generated by those tourists is relatively low with ungenerous daily expenditure per person or not satisfactory enough for those implicated within this industry.

There are some other destinations, also focused on Sun and Sea, but offering a differentiated product, in terms of elitism and exclusory. That is why these areas are not considered mass tourist destinations and the prices are higher, limiting the access to those tourists who able to afford it. Although these tourists are looking for same model of product, they also search to differentiate themself through the price. They aim for uniqueness and exoticism with great richness in the landscape and high level of sustainable tourism.

In the specific case of Benidorm, there is a consensus within the interviewees when it comes to identify the tourists coming to the city. They belong to middle and working classes, both Spanish and European, highlighting elderly and English segments. The group of elderly is channeled by the IMSERSO. Benidorm receives as well senior citizens who organized their trip through pensioners' associations that offer special prices to TT.OO for winter seasons. Obviously, this type of tourism focused on populations out of the business world has very limited capacity of expenses that, overall does not go over their pensions.

When the interviewees express their opinions about the tourists targeted by Benidorm they estate "in Benidorm there are only senior tourists and English people getting drunk for small amount of money (...) there are old people with bags of food and they eat in front of the sea, they do not go to bars or restaurants, they do not consume anything" (Cafeteria staff). They are sure that the tourism has this low quality because it is focused exclusively in Sun and Sea, however they are conscious that "Benidorm beaches are wonderful, but as well there are many other destinations with beaches and we must offer something else" (Civil servant). A bank manager states, "Elderly tourists don't create any conflict but they do not spend money (...) cheap tourism does not benefit Benidorm". However some respondents believe that this dependency is also favorable for the city, "I hope the tourist target that Benidorm has will be with us forever" (Tradeunion representative).

\section{HOTELS}

Within the tourism industry, the hospitality is one of the basic pillars. The hoteliers have been always linked to the practice of tourism. The origin of hotels runs parallel to the very first development of tourism. Along the years, the hospitality industry has faced important issues and changes, but its main purpose is still the same: to provide accommodation for those people travelling out of their usual places of residence. Hotels can operate throughout different business models of management, however there are two main axes that will shape their options: management of independent hotels or management through integration or grouping with other establishments [5].

Benidorm offers one of the largest collections of hotels across the Mediterranean: 150 hotels and 40.000 beds which through the years Benidorm has renovated constantly. And it is about hotels, that the interviewees state the best opinions. For instance "without competence, this is the miracle of Benidorm" (Politic PP) and a journalist claims "the number of hotels that Benidorm has, does not have it any other tourism destination with such a good relationship between value-money". There is an agreement on the proper state in which hotels are and they are also convinced that it is one of the best things that Benidorm has. "There is an exemplary hotel industry" (Tourism writer). The positive comments are also about the service provided within the hotels, specifically about the buffets:

"... The buffets are extremely good; I have not been in any hotel of the world with this relationship value-money. Here the buffets are extraordinary, you can find more than 70 or 80 different products (Researcher)."

The interviewees express also their disappointment and concern with some negative aspects related with human resources management within the hotels of Benidorm. They perceive a deterioration spite of its importance, saying that "We truly must take care of the customer service, it should be the center of the business. The center is not the hotel itself, it is not the employee, not even the owner. The center of the hotel industry is the customer" (Political PSOE). They also say “ The quality of treatment received by the client has dropped down considerably" (Tourism technical). 
Furthermore, they blame the hotels concerning the type of tourist attracted to Benidorm, without high purchasing power, stating that hotels are the ones who "discredit the touristic product of Benidorm, dropping the prices and offering much less services, even more near the area called Rincon de Loix (Officer).

About what is known as "all inclusive" it is qualified as demolishing. They consider that this form of sale is responsible of the bad performance of the sector. They claim that "all inclusive" leads in negative results in terms of competence between hotels.

"...There are even hotels with advertisements of their restaurant menu at the door, with offers and low prices. They don't have enough with their guests; they try to attract persons walking by. The occupation has dropped; hotels were always full along the year and since new establishments opened, the competence between them has increased and they have to fight in terms of prices. Before they had enough with the overnight stays, but now they try to make them stay inside the hotel. This policy is very detrimental for the village. (Hospitality association).

\section{HUMAN RESOURCES}

In general, salaries within hospitality industry are considered lower in comparison with other industries. There are several reasons to explain this situation [6]. Firstly, many of the employers are not qualified, for instance, housekeepers, cleaners, helpers, sub chefs, portieres, butlers, etc. In addition, business people consider that many of these job positions do not need to be qualified. Moreover, positions where staff need certain level of qualification such as guest relations, where they must have high levels of languages, managers do not recognize it.

It also goes against the need of high-qualified human resources the fact that many contracts are temporary, with very high turnover rates. Lastly, it should be noted that in areas where there are no alternatives to tourism, there is an opportunity cost zero or insignificant, associated with the employment of others sectors. Due the lack of alternative job opportunities, the tourism becomes a monopolistic industry, buying labor services; hence the price decreases, just as it happens in Benidorm.

It gives the impression that it is not taken into consideration that human resources is one of the key factors within the service sector. It is recognized an essential link when it comes to value the quality of the service perceives by guests Lillo [7]. For this researcher, the human capital in tourism is inextricably linked to the quality of the tourist product, so that the competitiveness of the companies are closely linked to the professionalism of the workers. It seems certain to have the best care with service customers, specially considering the we now live in societies constantly changing with more demanding guests, needing better treatment and services received. So, human labor constitutes the most important competitive resource, until the point of considering their formation and development not as a cost but as a perfect investment strategy [8]. However, for many years the tourism industry does not have a good reputation as far as employment is concerned. There are many authors who consider the need to overcome this negative image that across the time has gained strength and that it is building a barrier in term of recruitment and selection of employees with adequate training and welleducated [9]. In conclusion, bad job conditions due to unattractive shifts, slight possibilities to be promoted, low salaries and seasonal jobs, are some of the facts stimulating this negative image [10].

In the case of Benidorm, the respondents perceive human resources as the most conflictive issue and the one that more attention requires. If it continues like this, they claim, it is going to affect -for some ones it is already affecting- negatively the tourist image of the city. One of the respondents state, "there are workers within the tourism industry that really need the job" (PSOE Politic), other respondents support, "the situation of the human resources is characterized by the recruitment of workers without qualification or without training, most generally, immigrants. Hiring procedures must be as cheaper as possible, "in this field we have lost a lot. It is a sector where to work conditions are harsh and on top of it, the remunerations are very low (Local Journalist).

“...There are many workers without contracts, this situation is less common in the hotels but in the shops, bars and restaurants are increasingly paying less, who knows when you will be paid. Look, today is the $9^{\text {th }}$ and still I did not get paid, and even more, I do not have paid holidays. I can go on vacations, but I know that those days are not going to be paid. The labor situations are very bad for workers (restaurant employee)".

"...The employees are working with the threat that if they are not interested in the work conditions, right at the door there are 500 persons. We are back in the sixties. The welfare state has collapsed (...) there are not enough workers and when one gets sick, they fired him/her quickly and if it is a pregnant employee, even faster (Union representative)."

"...About Human Resources, I have to say that there is a big lack of professionalism, to find a good leader, head department or good marketer with knowledge it is difficult. Tourism students 
do not want to work in Benidorm because there are no opportunities to progress. Listen, I give you an example, I am already two months looking for people who wants to work in middle positions. There are many waiters able to remove tablecloths and to serve cocktails, but if you increase a bit the service level with some knowledge of English... it is very difficult, you do not find anyone (Hotel manager).

\section{CONCLUSIONS}

Once all social agents directly affected by the tourism development carried out in Benidorm have been interviewed, we can assure the article has reached its main objective.

In this paper, different opinions from a large group of stakeholders of Benidorm, as a tourism destination are reflected. The range of responses has required the breakdown of the findings by topics of interest:

1.- As the image is concerned, there is a high percentage of the interviewees who perceive the image of Benidorm as main attractive reason, however they claim inadequate financial investments to improve the image of hedonic destination for the tourist profiles that Benidorm is looking for.

2.- Concerning the tourist profiles coming to Benidorm, almost all answers were similar. They confirm that Benidorm focuses on two types of visitors with same economic levels: English and elderly tourists. This has been analysed by the respondents from two perspectives. On one side, it is a tourist that knows what he or she wants, they like Benidorm, therefore they will not change destination, becoming a loyal and assured guest. On the other hand, some of the answers criticize the limited potential profitability that this target market provides.

3.- The most remarkable answers throughout this paper rest in what the hotels are concerned. The respondents were very optimistic when it comes to value the quantity. Nevertheless, not just the vast range of hotels shall be viewed as the only element within this subsection, but the quality characterizing the service provided by employees to customers is, according to social agents questioned, even more important, and unfortunately, the critics were overwhelming indicating the lack of professionalism in what the treatment perceived is concerning.

4.- Specifically in this aspect and as noted above, the poor human resources management directly affects the quality of the product provided. From the responses obtained, there is a clear demotivation and insecurity in the workplace. Neither is recognized the qualification, the salaries are encouraging or the contracts are interesting, so therefore, efforts are minimized affecting the positive perception of the image of Benidorm.

\section{References}

[1] GUTIÉRREZ BRITO, Jesús (Coor.). 2007. La Investigación Social del Turismo. Perspectivas y aplicaciones. Madrid: Thomson Editores.

[2] JANOSCHKA, Michael. 2011. "Imaginarios del turismo residencial en Costa Rica. Negociaciones de pertenencia y apropiación simbólica de espacios y lugares: una relación conflictiva", en MAZÓN et all (eds.) Construir una nueva vida. Los espacios del turismo y la migración residencial. Santander: Editorial Milrazones.

[3] ANDREU, N.; GALACHO, F.B.; GARCÍA, $\mathrm{M}^{\mathrm{a}} \mathrm{y}$ LÓPEZ, D. 2005. "Técnicas e instrumentos para el análisis territorial", en ANTÓN y GONZÁLEZ (coordinadores) Planificación territorial del turismo. Barcelona: editorial UOC.

[4] ANTÓN, S; FERNÁNDEZ, A. y GONZÁLEZ, F. 2007. "Los lugares turísticos", en ANTÓN y GONZÁLEZ (coordinadores) A propósito del turismo. La construcción social del espacio turístico. Barcelona: Editorial UOC.

[5] MAZÓN, Tomás. 2001. Sociología del Turismo. Madrid: Editorial Ramón Areces.

[6] BULL, Adrian. 1994. La economía del sector turístico. Madrid: Alianza Editorial.

[7] LILLO BAÑULS, Adelaida. 2009. "El papel del capital humano en el sector turístico. Algunas reflexiones y respuestas", en Cuadernos de Turismo, $\mathrm{n}^{\circ}$ 24, pp. 53-64.

[8] JORGE, Alberto et all. 2005. Recursos Humanos en empresas de Turismo y Hostelería. Pearson Prentice Hall

[9] PARDO, Manuela y LUNA, Roberto. 2006. Recursos humanos para el turismo. Pearson Prentice Hall.

[10] FERNÁNDEZ NORIEGA, José Luis. 2004. La calidad en el turismo: mercado de trabajo. Formación y capital humano. Instituto de Estudios socioeconómicos de Cajamar.

Acknowledgemt

This article is the result of the work done in the Project $\mathrm{R}+\mathrm{D}+\mathrm{i}$ : "The social perception of tourism within the Valencian community. Sociological analysis and futurology". Ref. CSO2009-10293 (sub-GEOG) awarded by the Ministry of Sccience and Innovation, led by Tomás Mazón.

T. Mazón: Alicante, Spain. Fifteen of January of 1950. PhD in Geography (University of Alicante, Spain). BA in Geography and History (University of Alicante, Spain). He started his career in hospitality as a hotel employee and has held different positions over three decades. At the University of Alicante (Spain), he has been DIRECTOR and he is SECRETARY TO THE DEPARTMENT OF SOCIOLOGY I. He is FULL TIME PROFESSOR IN SOCIOLOGY OF TOURISM at University of Alicante, Spain. Over the years, he has taught degree courses, master and doctoral courses at the University of Alicante and has been invited to other universities as an expert in tourism. He also weekly collaborates as a tourism expert in a radio magazine. He has directed numerous national research projects about tourism issues funded by both public and private institutions. He has supervised several $\mathrm{PhD}$ projects. 
He has published widely in the field of tourism and urban planning. He is author of about 50 publications, including books and refereed articles. His last book, published in 2011 , is "Construir una nueva vida. Los espacios del turismo y la migración residencial".

Dr. Mazón is Founding Director of its research group "Tourism Development Studies" and of the Special Research Unit "Tourism and Leisure from Sociology". He is a member of the Governing Council of the University. He is advisor to the Alicante Municipal Tourism Board from 1999.

E. Delgado Laguna: Palencia, Spain. Twelve of November of 1983. Doctoral candidate in Sociology of Tourism (University of Alicante, Spain). BA in Hospitality and Tourism Management (Swiss Hotel Management School, University of Derby)

RESEARCH FELLOW at University of Alicante. Publications: Mazón, T., Delgado, E. ad Hurtado, J.A. "The success of a tourist destination: The Benidorm of Mario Gaviria" in Revista da Casa da Sobral Geography (in press). Ms. Delgado was named team member of the Chair of Studies of Tourism "Pedro Zaragoza Orts" at University of Alicante. 